\title{
Hladna vojna znanja?
}

Kdo ustvarja novo vrednost? Kapital? Ne. Tehnologija? Tudi ne. Kritični proizvodni dejavnik so lahko danes le še ljudje. Kar 70 do 80 odstotkov nove vrednosti ustvarijo zaposleni s svojim delom, $z$ razumom, ustvarjalnostjo, Kritični proizvodni dejavnik je zelo majhen in tehta le približno 1,3 kilograma - to so človeški možga$n i$. V svetu, kjer vsakdo kopira od vsakogar, res ni več pomemben kapital, temveč inovativnost. Človeški možgani so organizirani po holografskem načinu - deli odsevajo celoto. Laboratorijske raziskave so celo pokazale, da četudi odvzamemo 90 odstotkov možganov, bodo ti še vedno delovali. Kar poskusimo to narediti z avtom ali videom. Zdi se, da je imel John F. Kennedy prav, ko je - kljub temu, da so računalniki preplavili zemeljsko oblo, njihova zmogljivost pa presega vse napovedi futurologov-dejal: "Človek je še vedno najodličnejši računalnik". Le ljudje so lahko ustvarjalni, prinašajo nove ideje, izumljajo nova pravila in imajo svoja čustva -za sedaj.

In ta čudoviti mehanizem ni v lasti delničarjev, investicijskih skladov ali kateregakoli drugega telesa. George Soros morda res lahko vpliva na stabilnost valut in trga, ne more pa prevzeti nadzora nad človeškim znanjem. Vlade lahko usmerjajo gospodarstvo, toda ne vašega znanja. $V$ dobi informacij in dobi tveganj ga lahko nadzirajo, hoteč ali ne, le posamezniki.

$V$ letu 1998 je General Electric ustvaril več kot dve tretjini prihodka s finančnimi, informacijskimi in servisnimi storitvami. Jack Welch, glava $G E$, je takrat dejal, da 50 odstotkov njihovega kapitala predstavljajo zaposleni. Je nesporen kralj težke industrije postal mehak? Ali pa se je naučil brati številke tudi na drugačen način. Danes namreč kar 70 odstotkov vrednosti avto-

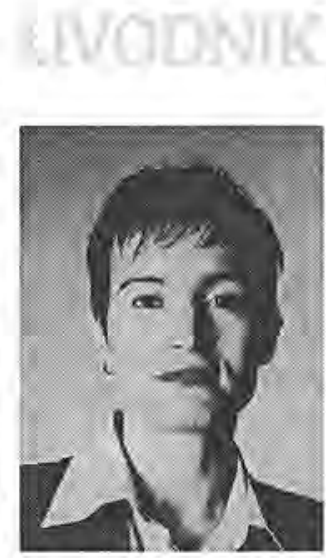

mag. Daniela Brečko mobila predstavljajo dodatne storitve in ne izdelek sam. Več kot polovica avtomobila je takorekoč nedotakliiva, skriva se $v$ inovativnih pristopih prodaje, $v$ vznemirljivih možnostih izdelave po meri posameznika, nekonvencionalne uporabe, in v dodatnih možnostih komunikacije s proizvajalcem po nakupu. Henry Ford že dolgo sodi $v$ preteklost, prav tako tudi njegove metode, ko se je še lahko pohvalil: "Kako neprikladno; če hočem par novih rok, obenem dobim tudi nove možgane". Danes se morajo podjetja najprej vprašati: Kdo pa potrebuje par fizičnih rok?

Znanje je že zdavnaj zamenjalo kapital pri doseganju konkurenčne prednosti. Zgodilo se je to, kar ni nihče prav zares verjel. Kapitalsko revnejša podjetja z velikim intelektualnim kapitalom s trga spodrivajo kapitalske mogotce. Če se ozremo v bližnjo preteklost, so države bogatele s pomočjo naravnih virov, delovne sile in kapitala. $V$ zdajšnjem času ne morete več sami zaslužiti denarja iz naravnih virov. Bill Clinton in Tony Blair sta že govorila o "hladni vojni znanja". Znanje je moč. In če je znanje moč, danes ta moč izvira od vsepovsod. Leta 1960 je v ZDA program MBA končalo 5000 študentov, danes ga kar 75.000 studentov. Leta 1967 sta v Angliji obstajala le dva programa MBA, danes jih je več kot 130. Znanje se širi in ga ni več moč ustaviti, še manj olastniniti. Lahko edino pritegnemo pozornost "lastnikov znanja" in jih prepričamo, da delajo za nas.

Vsa sodobna podjetja tekmujejo z znanjem, toda znanje je "pokvarlijivo blago", z datumom trajanja. Če nismo sposobni znanja zaposlenih unovčiti, izgubi svojo vrednost. Nenehne inovacije, revolucionarne ali evolucijske, so postale nujnost. Le z inovacijami, ki niso nič drugega kot 
sestaviti že znane stvari drugače, da bomo z novo kombinacijo lahko dosegali začasni monopol na trgu. Ali kakor je izjavil David Vice, direktor Northern Telecoma: $v$ prihodnosti bosta le dve vrsti podjetij - hitra in mrtva. Danes imamo opraviti z izjemno prefinjenimi kupci, ki cenijo le še inovativnost. Vnovi ekonomiji ni več hitrostnih omejitev in ni več časa za neznanje.

Res je, toda kaj naj storijo tisti, malce manj inovativni in malce manj izobraženi? Gre za ekonomski pogled in ekonomski hvalospev znanju, ki pa nosi v sebi klic hladne vojne, vojne med podjetji, državami, posamezniki. Kajti tisti, bolj izobraženi, dobivajo boljšse službe, kjer se lahko še naprej izobražujejo, malce manj izobraženi pa se sprehajajo od vrat do vrat, brez vsake motivacije za izobraževanje. Toda tudi tistim, ki imajo znanje, ni vselej udobno, saj imajo usak dan več dela. Organizacije od njih pričakujejo nemogoče in slabo plačujejo tiste, ki znanja nimajo. In kakšen je potem izhod? Za obe strani približno enak. Vsi delamo dlje. Tisti, ki imajo znanje, delajo dlje, ker želijo organizacije z manj ljudmi ustvariti več. Tisti, ki zaslužijo manj, pa so prisiljeni poiskati dodatno službo, da lahko preživijo. Če to ni Sizifova ekonomija? Ljudje so utrujeni in sčasoma postanejo neučinkoviti. C̆as je, da se vprašamo, ali smo to želeli. Ali res ni moč najti mehanizma za "pravično" porazdelitev znanj? Smo res želeli ustvariti hladno vojno znanja ali nam je stvar preprosto ušla iz rok pod okrilje (zgolj) tržnih zakonitosti?

Če naj bo kaj vrednota, potem je to znanje, znanje za vse, znanje za pravičnejšo družbo, znanje za enake možnosti. 